\title{
THREE POEMS
}

\author{
I picked a stone up \\ in the settlement, planted once \\ among an oblong of trees \\ which made sounds blowing through \\ and touching the intricate \\ vague, temporary mind. \\ Between trees, some young, some fallen \\ in earth, buried partly by grasses, I fetched out \\ a flat stone with marks on. \\ It heartened me. I grew \\ surprised that this thing, shaped by two hands, \\ and then incised on, \\ had come through. \\ What did it read, which words \\ gouging a vouchsafe over \\ bed, or fire; \\ how shall I be \\ communicated with, \\ now, here, between trees? A further scratch \\ might be sufficient. \\ A meaningful incision supposed \\ to show up lastingly.
}


In this miserable time,

a friend, dead, you had not

known, we come on the settlement.

You said, it admits us;

and lay coiled and flushed.

Further off, the reservoir

in viscous tension drew

down water off its sides.

Ditches here do not now stick

with blood, clay-streaked. When the refrigeration

of lust, pebble, and smoke

hardened over the sides of this dark box, an intruder

was knived, the cry hankering

momently, a wailing, an unleashing

of wanted life. The bird

hops and sinks.

The dead here patched a life

between trees, geese honking

flocculent in the snow.

And militia, the linked, harrying

mail of this kingdom

skimming the earth to break

into fine separate grains

the upturned bands of soil

weaken, dechain, and sink

under the plough rootlessly

as the soughing oil.

And over the ground a chain of mail

harrowed

the earth, and left

it.

How much forward do

we look, I asked you. 
The day's light merges itself on kitchen pans, with forks put to soak, thickened by egg. Haste darts onto the carpet, a pair of roaches, one with belly swollen. And mice nesting between foundations pitch a shrunk language voices sift through.

Can anxiousness wean itself?

We are beneath trees on the hill, moistened among them by darkness.

Some fitted together a settlement in hunger and community, the stone flaked into shape, placed, and clustering a group of heads over the new-born.

A glistening cry spreads milk along its web of threads.

This went. Went fast, and suddenly: the love, where it existed, cut by militia, the fractured blood greasing the double-dyked moat.

For what? But then, an Aenean moment, elate, and with fear, suppurating.

From between trees and these few stones, nothing; no, something: a man, bent, streaming from us with under his arm, in skins, a package, wailing, each seamed to the other in the lineaments of terror, without eyes, the man holding to some other husband's child or his own. 